\title{
The Empire Called and the Dominions Responded: Remembering the First World War in New Zealand
}

\author{
Sarah Murray \\ Canterbury Museum
}

\begin{abstract}
The centenary of the First World War offers a timely opportunity to reflect on experiences of war on the periphery of the British Empire. Although separated by more than 12,000 kilometres, the involvement of New Zealanders and Canadians during the conflict, both on the home front and battle front, share many similarities. Over one hundred years later, these experiences are at the forefront of the public consciousness as both nations commemorate the First World War in a number of ways. This article critically assesses commemoration activities in New Zealand by exploring a national museum exhibition in the nation's capital, Wellington, and a collaborative regional program in Canterbury. It explores in detail the approach of New Zealand's national museum, Te Papa Tongarewa, in its First World War exhibition Gallipoli: The Scale of our War before turning to focus on the work of Canterbury100, a collaborative group of cultural organizations situated in Canterbury. In reflecting on the strengths and weaknesses of these commemorative activities, it is clear museums and the public they serve benefit from a wide range of collaborations and that regional, national, and international perspectives offer depth and context to centennial commemorations. This article is part of a special collection of papers originally presented at a conference on "The North and the First World War," held May 2016 in Whitehorse, Yukon.
\end{abstract}

The Northern Review 44 (2017): 415-426 
On 4 August 1914, the British government declared war on Germany. As part of the British Empire, the dominions of New Zealand, Canada, Australia, and South Africa found themselves at war. Although separated by thousands of kilometres, the experiences of New Zealanders and Canadians were remarkably similar. Both sent men to fight for the "Mother Country," raised funds on the home front, and, like many other nations throughout the world, endured the legacy of the conflict in the decades that followed. Over one hundred years later, both Canada and New Zealand are in the process of remembering a conflict whose legacy has resonated across the world. Given the global ramifications of the First World War, there is much we can learn by sharing experiences of the war from other peripheral regions of the Empire.

To provide a point of international comparison, this article begins with an overview of the ways in which New Zealand participated in the conflict, paying particular attention to the similarities and differences with the Canadian experience. It then journeys forward in time to explore the ways in which this peripheral region of the Empire is commemorating the centenary of the "war to end all wars." Here, at the intersection of war, memory, commemoration, and museums, the response of Te Papa Tongarewa, New Zealand's national museum, to the centenary is examined before the article explores a more regional response from Canterbury, the largest urban and rural centre in the South Island. While in Canada the North is the periphery of the country, in New Zealand the opposite is true with the South the remote region-which, as Ken Coates has indicated, can also sometimes struggle with feelings of marginality and distance. ${ }^{1}$

Like Canada, New Zealand had several decades of shared history and culture as well as years of business and trade relations with Britain by the time war broke out in 1914. ${ }^{2}$ With the British monarch as the head of state, both answered the call of the Empire to fight together in the South African War. Their involvement in the First World War, just over a decade later, generated fundamental changes-changes across internal politics, society, economy, and foreign relations. The most recent governmentcommissioned book on New Zealand and the First World War explains that this conflict "had a greater impact on New Zealand than any other war in the country's history." ${ }^{3}$ Out of a population of one million people, 100,000 men served overseas. Over 18,000 of these recruits died, and a further 41,317 became casualties. Despite being at the edge of the Empire, some 18,000 km from Britain, New Zealand suffered a casualty rate higher than any other Allied country. ${ }^{4}$ For New Zealand, providing troops for 
the Empire was a significant component of its war effort. While initially recruits were raised as volunteers, the four recruiting districts had difficulty meeting their quotas by early 1916. Later that year conscription was introduced. New Zealand was particularly proud of its commitment to providing reinforcements; Australia, which twice voted no to the introduction of compulsion, was regularly derided in newspapers and cartoons. Canada and Britain, however, both of which had already introduced conscription, were clearly seen to be doing their bit against Germany. ${ }^{5}$ A total of 550 New Zealand women also served as part of the New Zealand Army Nursing Service and, within the 100,000 New Zealand soldiers who travelled overseas, 2,000 soldiers declared they were of Maori descent. ${ }^{6}$ As Peter Kikkert and P. Whitney Lackenbauer have found in the case of the Yukon, New Zealand soldiers were upheld as fine examples of colonial manhood-men of splendid physique with experience in harsh environments and good sporting backgrounds who would perform well in war. ${ }^{7}$ Maori, many suggested, had innate fighting abilities which would ensure success at the front. ${ }^{8}$ New Zealanders saw action first in Egypt before Gallipoli, and then on the Western Front in battles such as the Somme, Ypres, and Passchendaele. Both those who served and those who died are remembered in over 500 memorials across New Zealand's landscape. In recognition of New Zealand troops landing on the Gallipoli peninsula in 1915, these memorials are a focus of remembrance on Anzac Day, 25 April each year, as opposed to Remembrance Day on 11 November, which is often marked by other Allied countries.

Like Canada, patriotic activities on the home front saw citizens donate time, money, or goods to support the Empire's war effort. Thousands of New Zealand pounds were raised for a variety of causes - for the starving Belgians in the early years of the war, through to caring for wounded servicemen and assisting reintegration back into society and employment in the later years of the conflict. Both countries were committed to the concept of "practical patriotism" to ensure Allied triumph over a common German enemy, particularly by encouraging citizens to buy goods made in their own country or in Britain. ${ }^{9}$ So committed were Cantabrians to this concept that a local area, German Bay, changed its name. ${ }^{10}$ For New Zealanders, feeding the Empire involved not wheat or salmon like Canada, but rather butter and meat from the farms dotted throughout the plains of the country. Unlike Canada, New Zealand women had already been granted the vote in 1893 so discussions around women's suffrage did not feature to the same extent. Neither did discussions around prohibition dominate strongly, although temperance campaigners convinced the 
government to close bars at six o'clock each evening as a temporary wartime measure (one that was in place until 1967). Just as in Canada, however, New Zealand was not without dissent. Organized labour and anti-war activists clearly spoke out against New Zealand's involvement, and there was considerable concern over the idea of equality of sacrifice. For most, life at home in both countries was full of anxieties and long goodbyes before the realities of death, mourning, and loss reverberated. ${ }^{11}$

One hundred years on from this conflict, museums and cultural institutions are playing a significant role in the commemoration of personal and national stories and experiences, meeting the public's expectation that museums serve a commemorative purpose. ${ }^{12}$ In New Zealand, the government and two major museums commissioned a leading research company to explore public knowledge and expectations. Like Canada, where public knowledge of the First World War is limited, the survey identified that $66 \%$ of New Zealanders had basic to no real knowledge of the conflict. More than half believed that more New Zealanders were killed at Gallipoli than on the Western Front when, in fact, the number who died on the Western Front is three times greater than those who died at Gallipoli. Furthermore, $24 \%$ were likely to visit an exhibition at a local museum, the highest percentage of attendance at any proposed centenary commemoration activity. ${ }^{13}$ Clearly, commemorative exhibitions are a significant format in which to share information about the conflict and to help both a New Zealand and international audience understand more about the First World War.

What forms have commemorative activities in New Zealand taken? An increase in community interest in the conflict has been mirrored by an increase in websites, talks, and displays. Lotteries funding in excess of NZD \$17 million has facilitated a proliferation of research projects and publications, refurbishment of war memorials, craft projects, travelling shows, and the expansion of valuable online resources such as the Auckland War Memorial's Cenotaph, which is a database of New Zealanders who served in all conflicts. ${ }^{14}$ In New Zealand's capital, a new museum curated by Peter Jackson of Lord of the Rings (film) fame was established. ${ }^{15}$ Yearly events across the centennial period remind us of the duration of the conflict. The poignant Fields of Remembrance project by the Returned Servicemen Association, for instance, sees a cross for every serviceman and woman killed in the First World War erected in their province on Anzac Day each year. ${ }^{16}$

On the whole, despite the emotion and effort involved, New Zealand museums have commemorated the centenary in predictable ways with 
a strong focus on Gallipoli-a military campaign often referred to as the birthplace of New Zealand's national identity - to the extent that New Zealand's national museum, Te Papa Tongarewa, in its First World War exhibition, Gallipoli: The Scale of Our War (April 2015-April 2019), focused on just this one engagement. Gallipoli was New Zealand's first major engagement in a failed attempt to relieve the stalemate of the Western Front along with other Allied forces. A "costly failure," the campaign lasted eight months from April 1915 and "had no significant effect on the outcome of the war." ${ }^{17}$ Despite this, the event has achieved a mythic status in New Zealand, perhaps to the same extent that Vimy Ridge achieved mythic proportion in Canada or the Somme in Britain. It is unsurprising then that a museum keenly interested in the concept of national identity chose to focus on this battle.

Te Papa's Gallipoli exhibition was co-created with Weta Workshops, a world-leading design and effects agency based in Wellington. The result was an exhibition portraying eight 2.4-times-human-size models of New Zealanders involved in the conflict, together with their stories and a range of digital media, soundtracks, and original objects. As they enter the display, visitors encounter a dramatic model of Spencer Westmacott, a farmer who lost his right arm on the very first day at Gallipoli. They are then ushered into an area where the brief context of the First World War is explained, and then immediately launched into the Battle of Gallipoli. Over the course of the exhibition, visitors can engage in-depth with stories of the eight models through summary information boards, cartoon strips, artifacts from each person, and digital interactives that provide information and additional objects relating to the person's life before and after the war. For instance, the model of Jack Dunn, a newspaper reporter from the Wairarapa region, clearly shows his utter exhaustion; photographs of the peninsula are displayed on a projector behind him and the words from his diary record his feelings at the time. As the exhibition continues and the visitor explores surrounding information, it becomes clear that the model represents the night Dunn fell asleep on sentry duty while at Gallipoli. He was sentenced to death but this was later remitted. While detailed information is provided in relation to the stories of the eight individuals showcased, a plethora of other information, stories, and objects line the walls of the remainder of the gallery. The models and information provided are extraordinarily detailed and, using an advisory group of New Zealand's leading First World War historians, exceptionally accurate; you can see the hair follicles on skin, the emotion, tiredness, 
sorrow, and despair in the faces of each model, and details right down to the correct species of flies on the peninsula in $1915 .^{18}$

The evocative display and text written in a first-person perspective drive a high level of emotional engagement. ${ }^{19}$ The carefully curated personal stories, including a diversity of "age, occupation, rank and unit, geographical origin or domicile, gender and ethnicity," were developed in partnership with descendants. ${ }^{20}$ Creating strong relationships with the families revealed "private collections and personal memories" and allowed curators to feel "empowered and trusted to tell someone's story in public." ${ }^{21}$ Although, as one curator commented, working with descendants meant "you can find yourself negotiating with an array of descendants across the world, with complex agendas and issues." ${ }^{22}$ Visitor engagement occurs at a variety of levels with the material presented, but also through a number of means by which they can share their own experiences, memories, and thoughts. ${ }^{23}$

The curators are to be congratulated for their dedication to biculturalism. Although only 600 of the 17,000 New Zealand soldiers at Gallipoli were Maori, the curatorial team ensured a Maori figure, Rikihana Carkeek, was included. Reinforcing this, the exhibition soundtrack includes waiata (song), karakia (prayers), and himene (hymns). As the display considers a subject of great significance, a subject which deals with death and hurt, visitors are also provided with water to whakanoa or cleanse themselves from tapu (sacred) to noa (to be free of tapu). ${ }^{24}$

While there are many aspects of the Gallipoli exhibition that deserve celebration, three features could cause unease. Two of these were interactives. The first of these offered visitors the opportunity to view a Turkish soldier through a periscope and take a "sniper shot." With little information or context provided, this could be considered gratuitous. The second feature, a digital display, had the potential to make visitors feel uncomfortable due to its challenging content and perhaps its somewhat ghoulish character, even if it did seem to evoke the interest of young men in the audience. The display allowed visitors to choose a particular weapon, such as a grenade, that was then thrown at a digital skeleton on the screen. The screen showed the effect of such a weapon on the human body. The third area of unease related to a missed opportunity. The exhibition neglected the opportunity to engage meaningfully with the effect of Gallipoli on the home front; where were the stories of loss and grief for the mothers, sweethearts, and sisters who were at home? What messages and support did they send to their boys at the front? For Gallipoli, the exhibit, the scale of our war was overseas, not at home. 
As James Gardner wrote in The Public Historian in 2004, the challenge for museums is to engage visitors with a contested past, particularly highlighting tensions around the concepts of patriotism and unity. ${ }^{25}$ While Gallipoli is successful in intimate and personal connections, it lacks an additional layer of meaning or complexity; it continues a comfortable myth taught in New Zealand schools about the formation of national identity, without interrogating the concept. In a recent article, one of Te Papa's curator's wrote: "[ $t]$ he giants have generated a slight dusting of negative comments, with critics comparing their size and realism to that of Soviet Socialist public sculpture. The implication of such an analogy is to suggest that Gallipoli is an artless government mouthpiece that forecloses debate about the impact of the War, inspiring in its place a triumphalist myth of nation building." While the curator suggests the reverse, that Gallipoli was intended to "unsettle standard readings of the war," the extent to which this has been achieved is open to debate. Without explicitly providing guidance in the form of text, objects, or interactives, the museum leaves those visitors without knowledge of the war in a no better informed position. ${ }^{26}$ For an exhibition that cost in excess of NZD \$8 million and is only available in Wellington, questions may well be raised about the extent to which this display truly interrogates the scale of New Zealand's war. ${ }^{27}$

Those thoughts aside, all in all Gallipoli is a powerful emotional journey and if visitor numbers are an indication, Gallipoli has certainly been a success with 230,000 visitors during its first four months. ${ }^{28}$ The engagement with the museum's subject matter has been one of the most reinvigorating and successful partnerships seen in New Zealand museums for many years. Given the emotion invested in the Gallipoli myth, this is an extraordinary achievement. The museum's curators have also shared what they've done, how they made choices and why, which offers both their contemporaries, and those that follow them, the opportunity to learn, develop, and grow from their experiences. ${ }^{29}$

Although Te Papa represents a national approach to commemorating the war, what can a regional perspective, in an area on the periphery of Empire, offer us? In a place undergoing a period of recovery following a series of devastating earthquakes in 2010 and 2011, how has Canterbury, the largest region in the South Island of New Zealand, responded to the centenary? Unsurprisingly, long-term planning for commemorative activities in the region were severely disrupted by the series of earthquakes and more than 15,000 aftershocks that followed. Many heritage institutions were inaccessible for periods of time before facing lengthy remediation 
projects, many of which may take decades. Although a limited extent of long-term planning took place, for most heritage professionals, their focus was on saving what little remained of Canterbury heritage, in amongst their own personal recovery.

By 2013, however, most immediate earthquake concerns had been addressed and heritage communities were in a better position to look forward. A local heritage networking group, Cantage, met and raised the idea of working together to recognize the start of the conflict in such a way that resourcing could be pooled so that no one organization bore the brunt of such activities at a time when energy and resourcing were at their limit. A number of institutions expressed interest in the idea and thus a steering committee was formed with major players representing over a dozen institutions in the region. The committee developed two guiding principles: first, that their focus was on community stories, and, second, that the group wished to ensure a legacy of collaborative activity for Canterbury heritage groups.

Together, the team devised a program with three major outcomes. The first of these was the design, development, and curation of an exhibition that could travel around venues. Around the outside of the exhibition ran panels that provided a chronology of the international context to the war as well as happenings both in Canterbury and overseas. In the centre of the gallery, three exhibition cases showcased changing stories relating to the war. When the exhibition opened, this featured the story of the Wizard of New Zealand's mother, who lived through Zeppelin raids in the United Kingdom; the story of rugby All Black Captain Richie McCaw's Great Uncle from Dunedin; and singer Hayley Westenra's grandfather. All three of these cases clearly presented the message that Canterbury had stories that crossed national and international boundaries. The story of Canterbury's war included people of German, Austrian, and Canadian descent, for instance, who had moved to Canterbury since the war, just as much as those who had always lived in the region.

The second major focus for the Canterbury100 group was an event day. Feedback from the benchmark survey and local community made it clear that many lacked knowledge of the First World War and, therefore, how to find information about the objects they cared for or the stories their families might connect to. As a result, the group ran a day long program that brought experts from around the country to Canterbury to help locals share their stories and identify their collections. Hundreds of 
locals brought items for identification while their children were happily entertained making models of First World War aircraft.

Given the legacy aims of the project, and a desire to connect with the community, the group's third goal was to develop a website where organizations and individuals could share their objects and stories. ${ }^{30}$ This would not only ensure visitor interaction with the project but also provide these visitors with the opportunity to tell their stories. As a helpful sideline, it would also act as a potential source of objects for future exhibitions. The website launched in 2014 and online visitors can submit stories, information on people, or information on objects. Members of the public have gone to extraordinary lengths to piece together the history of their families, and these are both heart-rending and beautiful stories. While Canterbury100's first two activities were achieved with in-house resourcing, the third obtained a $\$ 30,000$ lottery grant. To put this amount in perspective, it was less than $0.4 \%$ of the funding received by Te Papa for their major exhibition.

Canterbury100 has delivered huge benefits in terms of strengthening collaborative relationships in the region. All team members went above and beyond to deliver, working late nights and weekends so that the region would be able to offer something at the start of the centenary. In doing so, managers and directors who saw the importance of what Canterbury100 was doing, even within the competing demands of other priority projects, offered incredible support. Not unexpectedly, there were also tensions in working collaboratively. Most team members worked on the project in addition to their existing workloads, so finding the time and space to contribute fairly was often difficult. Most team members were also from the curatorial or content side of organizations and the group quickly found that it lacked communications and marketing focus (and funds). Thankfully, the organizations involved made contributions towards this area from in-house budgets. Probably the biggest issue related to the expectations of individual contributors; the way they wanted group material to look, feel, or read. Again, as with all collaborations, negotiation and compromise were at the heart of discussions, as well as clearly identifying and addressing expectations and concerns early on in the process. While there were elements of each of the three programs that were not perfect, they were of a standard that all parties could accept.

While museums and heritage organizations often undertake collaborative work, Canterbury100 did so on an ambitious scale within a tight time frame. The most significant aspect of Canterbury100 has been 
twofold. First, the long-term benefit or legacy of the group continues to bear fruit; these networks are called on now for a variety of projects, sharing of information and plans happens both at a high level and at the arms and feet of the organization. Rather than competing for funding, visitors, and collections, this collaboration has generated a greater shift than any other relationship to date in ensuring our heritage organizations and professionals work together. These networks are already passing down through generations as new curators become involved and as old move on. These relationships will be particularly valuable in the period of disruption that will continue in Christchurch over the coming decade or more, as most organizations face periods of future closure, rebuild projects, funding shortages, and space shortages. They now have structures in place to plan together, to work together towards solutions that function not only for the organizations involved but for the community we exist to serve. Which brings us to the second most significant outcome of Canterbury100-a clear focus on the visitor, the families, and the history that such organizations exist to care for.

Canterbury100 also eased the pressure on individual organizations to produce their own exhibitions. At Canterbury Museum, for instance, the exhibition team now has space to consider what shape their major regional exhibition might take and to undertake visitors research to help inform this. As a result, Canterbury Museum will open a $400 \mathrm{~m}^{2}$ exhibition in 2017 that focuses on personal stories and the legacy of war. The museum's market research clearly informed them that "Rather than suffering a WW1 exhibition 'fatigue' ... the market is hungry for new angles that go beyond the Gallipoli/Anzac focus that often preoccupy coverage and dominant narratives in New Zealand." ${ }^{31}$ While exhibitions like Gallipoli have heightened the public's expectations, it is clear that there is an appetite for further displays that showcase the war on emotional and intimate levels and allow audiences to share their personal responses and reflections.

As historians predicted, the centenary of an event like the First World War has seen a flurry of activity. Public historians, academics, and curators alike have a responsibility to ensure we help the public to understand the impact of these events, their complexity, what we can learn from them, how they affect our choices now, and their relevance to modern warfare. We also have a responsibility to locate this locally, but also on a regional, national, and international scale. This event did not take place in isolation and there is much we can bring to enhance understanding by situating our work within broad cross-national comparisons. Our experiences in New 
Zealand have shown the value of collaborations, both with other heritage organizations and with wider community partners. Perhaps, one hundred years on, there is much we can learn from each other, and do together, to commemorate this centenary.

\section{Author}

Sarah Murray is curatorial manager at Canterbury Museum in New Zealand.

\section{Notes}

1. Ken Coates, "Opening Remarks," The North and the First World War Conference, Whitehorse, Yukon, 9-12 May 2016.

2. James Belich, Making Peoples: A History of the New Zealanders from Polynesia Settlement to the End of the Nineteenth Century (North Shore, NZ: Penguin, 2007); James Belich, Paradise Reforged: A History of New Zealanders from the 1880s to the Year 2000 (Honolulu: University of Hawai'i Press, 2001).

3. Damien Fenton, New Zealand and the First World War 1914-1919 (Auckland: Penguin Books, 2013), 106.

4. Ibid.

5. See, for example, New Zealand Free Lance, 4 Jan 1918, 3.

6. Peter Kikkert and P. Whitney Lackenbauer, "'Men of Frontier Experience': Yukoners, Frontier Masculinity, and the First World War," The Northern Review 44 (2017), https://doi.org/10.22584/nr44.2017.000.

7. “Maori and the First World War," NZ History, accessed 18 Jul 2016, http:// www.nzhistory.net.nz/war/maori-in-first-world-war/introduction.

8. $\quad$ Franchesca Walker, “Descendants of a Warrior Race: The Maori Contingent, New Zealand Pioneer Battalion, and the Martial Race Myth, 1914-19," War and Society 31, no. 1 (2012): 1-21.

9. See, for example, New Zealand Free Lance, 18 Feb 1916, 3.

10. Sun (Christchurch, New Zealand), 5 Jan 1916.

11. Fenton, 46-47.

12. James B. Gardner, "Preserving/Shaping/Creating: Museums and Public Memory in a Time of Loss," in The International Handbooks of Museum Studies: Museum Theory, ed. Andrea Witcomb and Kylie Message (United Kingdom: John Wiley \& Sons, 2015, 2011).

13. Colmar Brunton, "Benchmark Survey of the New Zealand Public's Knowledge and Understanding of the First World War and its Attitudes to Centenary Commemorations," Report prepared for the First World War Centenary Programme Office, 4 Mar 2013. 
14. Ministry for Culture and Heritage, "Lottery funding to commemorate the centenary of the First World War," accessed 6 Mar 2017, http://www.mch.govt.nz/news-events/news/ lottery-funding-commemorate-first-world-war-centenary.

15. The Great War Exhibition, accessed 22 Jul 2016, http://www. greatwarexhibition.nz.

16. Fields of Remembrance New Zealand, accessed 18 Jul 2016, http://www. fieldsofremembrance.org.nz/Projects/Regional+Fields+of+Remembrance $+\mathrm{P}$ roject.html. The majority of commemorative activities are listed here: New Zealand's First World War Centenary, accessed 24 Apr 2016, http://ww100. govt.nz.

17. Ian McGibbon, ed., The Oxford Companion to New Zealand Military History (Oxford University Press: Auckland, 2000), 190-198.

18. Kirstie Ross, "Conceiving and Calibrating Gallipoli: The Scale of Our War," Museums Australia Magazine, 24, no. 1 (2015): 22-30, 27.

19. Ibid., 29.

20. Ibid., 27; Personal communication with Te Papa Tongarewa Curator Stephanie Gibson, 12 Apr 2016.

21. Ross, 27; Personal communication with Te Papa Tongarewa Curator Stephanie Gibson, 12 Apr 2016.

22. Personal communication with Te Papa Tongarewa Curator Stephanie Gibson, 12 Apr 2016.

23. James B. Gardner, "Contested Terrain: History, Museums, and the Public," The Public Historian, 26, no. 4 (2004): 11-21, 20.

24. Ross, 27; "How Many New Zealanders Served on Gallipoli?," accessed 4 May 2016, http://blog.teara.govt.nz/2016/03/23/how-many-new-zealandersserved-gallipoli; Puawai Cairns, "The Wait and the Fight - Telling Maori WW1 Histories and the Search for Alternative Platforms," Te Pouhere Kōrero (forthcoming), http://www.academia.edu/24306500/The Wait and the Fight Telling Maori WWI Histories and the search for alternative platforms.

25. Gardner, "Contested Terrain," 12.

26. Ross, 27.

27. Olivia Wannan, "Larger-than-life Gallipoli Exhibition opens at Te Papa," accessed 22 Jul 2016, http://www.stuff.co.nz/national/last-post-firstlight/67800631/largerthanlife-gallipoli-exhibition-opens-at-te-papa.

28. Ross, 23.

29. Gardner, “Contested Terrain,” 16-18; Cairns; Ross, 22-30.

30. See Canterbury100, accessed 22 Jul 2016, http://www.canterbury100.org.nz.

31. Morris Hargreaves McIntyre, "New Angles, New Histories: Formative Evaluation of Canterbury Museum's 2017 WW1 Exhibition," March 2016, 3. 